\title{
The Influence of Participatory Leadership, Quality Culture, and Job Satisfaction on Lecturer Organizational Commitment (Case Study of Universities in Indonesia)
}

\author{
Suryadi Damanik ${ }^{1}$, Benyamin Situmorang ${ }^{2}$, Rosmala Dewi $^{\mathbf{3}}$ \\ 1,2,3 Universitas Negeri Medan, Indonesia \\ suryadi67@unimed.ac.id
}

\begin{abstract}
This study aims to determine the effect of participatory leadership on lecturers' organizational commitment, the influence of quality culture on lecturer organizational commitment, the effect of job satisfaction on lecturers' organizational commitment, the influence of participatory leadership and quality culture on job satisfaction and the commitment of lecturers' organizations at the State University of Medan, Indonesia. The sample is 202 lecturers. The instrument used a questionnaire, the data were analyzed using Path Analysis. The results of the study found that there was a significant influence of participatory leadership variables on job satisfaction. Quality culture has a positive effect on job satisfaction. Participatory leadership has a positive effect on organizational commitment. Quality culture has a positive effect on organizational commitment and job satisfaction also has a positive effect on organizational commitment. Taken together, participatory leadership, quality culture and job satisfaction have a positive effect on organizational commitment.
\end{abstract}

Keywords

participatory leadership, quality

culture; job satisfaction;

organizational commitment

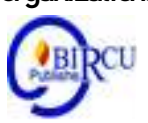

\section{Introduction}

Organizations are systems and human activities in collaboration (1993). Along with that, organization is considered as the coordination of the rational activities of a group of people to achieve some general goals through work and functions under one hierarchy and responsibility (Mangkunegara, 2001). This statement reflects that the organization has certain structured characteristics and objectives related to one another and relies on human communication to coordinate activities in the organization. Therefore, an organization needs employees who have high organizational commitment.Organizational commitment reflects the psychological state that binds the individual to the organization. The psychological state can be described as the employee's relationship with the organization and is related to the decision to continue or stop membership in the organization (Meyer, Allen, Smith, 1993).

Lamber, Hogan and Jiang, (2008) suggest that organizational commitment is an important factor in organizational success. Organizational commitment involves employees' engagement in the organization in achieving goals by showing their involvement in the organization. Investigating organizational commitment and its determinants has come to the attention of organizational behavior researchers. Organizational commitment has become an important issue for every organization. Most of the research is carried out in the context of business organizations and the healthcare industry. In other words, very little research has been conducted in educational institutions, for example lecturers in tertiary institutions.Fink (1992) 
notes that developing the leadership literature suggests that lecturer commitment is gradually being recognized as the most effective path to college success. Current research concerns the commitment of lecturers' organizations for several reasons. First, organizational commitment is an internal strength that comes from the lecturers themselves which is very important for the nature of work in educational institutions. The nature of work with greater responsibility, variety, and challenges demands lecturers with a high level of organizational commitment. Second, it is an external force coming from the government to meet accreditation standards that depend on the commitment of the lecturers of each university.

Organizational culture is a set of assumptions or systems of beliefs, values, and norms developed in organizations that serve as guidelines for behavior for its members to overcome the problem of external and internal adaptation. Organizational culture is a pattern of beliefs and organizational values that are believed and imbued by all members in doing work as an appropriate way to understand, think, and feel about related problems, so that it will become a value or rule within the organization. This will encourage members of the organization to work harder and create work motivation. (Mangkunegara in Arif, 2019)

Organizational culture according to Rosie in Sihombing (2020) can be defined as an organization's "personality" which means something that is inherent in the organization, and can even be said of company assets. Jalal (2017) shows that organizational culture can be part of the key to leadership decision making and organizational achievement.

Organizational culture is a pattern of basic assumptions that are found, created or developed by an individual or a particular employee with the intention that government agencies can overcome and overcome problems that arise. Organizational culture becomes a common reference including human resources (HR) in interacting in government agencies. Therefore, organizational culture greatly influences the fundamental aspects of organizational performance. (Syardiansah et al, 2020)

Understanding individual commitment orientation is very important to support the teaching profession. Tsui \& Cheng, (1999) stated that lecturer commitment is an important predictor of work performance and educational quality. Fostering organizational commitment among lecturers is important.maintain membership in the organization.Therefore, an organization must be able to create conducive situations and conditions so that employees will not feel bored and lazy which can lead to weakened morale. Luthans (2006) states that organizational commitment is determined by: individual variables which include age and position in the organization; organizational variables consisting of job design, values, support and leadership style; and non-organizational variables. Meanwhile, Colquit (2009) states that organizational commitment is directly influenced by motivation and job satisfaction, while indirectly influenced by organizational culture, leadership, personality, abilities, through job satisfaction.

\section{Review of Literatures}

It is not easy to create job satisfaction since then, satisfaction can only be realized if the influencing variables, such as leadership and quality culture are well accommodated and accepted by all employees in a company. Gibson, et al., (1997) stated that job satisfaction is the attitude that workers have about their job. Employees who do not get job satisfaction will never achieve psychological satisfaction and eventually negative attitudes or behaviors will arise which in turn can cause frustration, otherwise satisfied employees will be able to work well, be full of enthusiasm, be active, and can perform better than employees who do not get job satisfaction. 
Remembering the quality culture is very important for an organization or company because it is related to company life. Quality culture pays attention to an organizational value system that produces an environment that is conducive to the formation and continuous improvement of quality consisting of philosophies, beliefs, attitudes, norms, traditions, procedures, and expectations that improve quality. According to quality culture is an organizational value system that produces an environment that is conducive to the formation and improvement of quality continuously (Goetsch; 2002, Tjiptono and Diana; 2003). Building such a culture requires continuous hard work and commitment from all parties (EUA, 2011). Why quality culture is important because it relates to the habits carried out in the organizational hierarchy that represent the norms of behavior that are believed by members of the organization. Quality culture is also a guarantee of quality and is integrated in an integrated quality management process that is oriented towards continuous improvement in an institution to achieve the quality of the product or service produced. A culture of high quality is a culture that is able to turn the organization into a single strength and have an impact in accommodating company goals.

One of the important elements in a company's management system, apart from quality culture, is leadership. The success of the organization in achieving its goals is inseparable from the leader's ability to manage the resources within the organization. Therefore, the role of leadership will determine organizational performance. Participatory leadership is a leader who delegates authority to others, encourages participation, relies on subordinates' knowledge to complete tasks, and relies on the respect of subordinates for influence (Richard, 2005). This leader will encourage employee commitment by providing organizational and managerial values to employees (Dolatbadi and Safa, 2011).

\section{Research Methods}

This research can be classified as ex post facto research involving 148 physical education teachers in SMA Kota Medan. The method in data collection is used by providing a questionnaire with five answer choices. The sampling technique used was proportional random sampling. The instrument used was first tested outside the sample to ensure valid and reliable instruments. The validity test used the produc moment correlation, while the reliability test used Croncbach alpha. Before testing the hypothesis, the analysis prerequisite test is carried out including the normality test and the regression linearity test.

\section{Result and Discussion}

This study aims to analyze and examine the influence of participatory leadership, quality culture, and job satisfaction on the organizational commitment of lecturers at the State University of Medan, Indonesia.

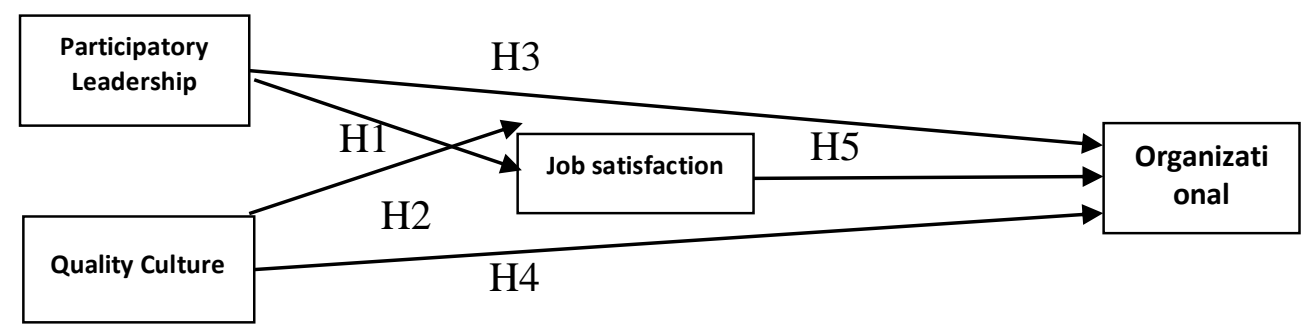


H1

: Participatory leadership ssignificant to job satisfaction

H2 : Quality culture has a significant effect on job satisfaction

H3 : Participatory leadership has a significant effect on organizational commitment

H4 : Quality culture has a significant effect on organizational commitment

H3 : Job satisfaction has a significant effect on organizational commitment

This research is an ex post facto research with a survey method. This research is also called exploratory research because it aims to determine the effect of exogenous variables on endogenous variables by using path analysis. It also aims to determine the influence of a variable on other variables, either direct or indirect (Sitepu, 1994).

The population of this research is all lecturers at the State University of Medan with a total of 790 people, provided that they already have an educator certificate and are not taking study assignments. So that the sample used in the research is a number of 202 lecturers who are determined based on the provisionsIsaac and Michael (Benyamin and Panendek 2017).

Participatory leadership is the ability of a leader to influence, invite, encourage, direct and / or mobilize staff, employees, and other citizens through their involvement in organizational activities so that they are willing to work hard voluntarily in an effort to achieve the expected goals (Northouse, 2013;Yulk, 2007; Newstrom, 2009). Indicators of participatory leadership variables are; (1) providing support for staff / employee efforts, (2) involvement in problem solving and decision making, (3) increasing two-way communication (consultation), (4) providing a sense of responsibility, and (5) fostering a sense of belonging.

Quality culture is a person's activity in meeting customer expectations in an institution in a sustainable manner (quality behavior) which is oriented to the organization's value system (Hong, 2008; Egle, 2009).The indicators of the quality culture variable are; (1) values, (2) norms, (3) beliefs, (4) morals, (5) innovative awareness, (6) competitive awareness, and (7) professional traditions.

Job satisfaction is the attitude or feeling of a lecturer interpreting his work that causes feelings of pleasure or displeasure with the implementation of the job ((Mullins, 2005; Colquitt, at.all., 2009). Variable indicators of job satisfaction are; (1) the job itself, ( 2) relationships between colleagues, (3) opportunities to progress and develop, (4) freedom in work, and (5) respect for work.

Organizational commitment is a form of one's attachment to the organization which is indicated by the level of acceptance of organizational values and a strong drive in making efforts to meet organizational goals (Colquitt, at.all., 2009; Robbin and Judge, 2011) Indicators of commitment variables Organizations are: (1) acceptance of the values and goals of the institution, (2) a sense of responsibility towards the institution, (3) a sense of pride and willingness to work hard for the institution, and (4) the desire to maintain membership in the institution.

The data analysis technique was carried out using the SPSS program computer aids in two stages, namely descriptively and inferential. The purpose of descriptive analysis is to describe the characteristics of the data in the form of mean, median, mode and variance. Inferential analysis is used to test the requirements of the analysis and research hypotheses. The analysis requirements test includes (1) normality test for each variable, the One-Sample Kolmogorov-Smirnov Test technique is used and (2) the linearity test for the relationship of each exogenous variable and the endogenous variable is used Variance analysis for the regression linearity test, with a significance level of $\alpha=0,05$. Hypothesis testing is performed using Path Analysis. Using Path Analysis, Al-Rasjid (1994) argues that when conducting path analysis. 
The results of this study partially show that participatory leadership has a positive direct effect on lecturer job satisfaction by $5.70 \%$. This implies that increasing participatory leadership will increase job satisfaction. The findings of this study are in accordance with the results of research by Stevens and Ash, (2001).,found participatory leadership gives employees more responsibility for organizational performance and for making planning and organizing decisions. Wagner, (2006) shows that participatory leadership has the potential to balance the involvement of managers and subordinates in information processing, which can give lecturers an influence on organizational decisions., and participatory leadership as an effort to create an environment that provides more opportunities for resource access (eg, autonomy, selfefficacy), resulting in higher levels of satisfaction and lower levels of fatigue. Increased job satisfaction is expected to be the result of expanding roles and feeling empowered by being part of the decision-making process, an expected outcome in an individualistic culture (Bogler and Somech; 2005).. Good participatory leadership will be able to increase the job satisfaction of Medan State University lecturers.

The results of this study partially show that the quality culture has a positive direct effect on job satisfaction of lecturers by $16.50 \%$. These results indicate an increase in quality culture will have an impact on increasing job satisfaction. Because the quality culture is an effort oriented towards continuous improvement in an institution to achieve the quality of the product or service produced, especially if the quality culture reflects a work culture which includes: shared values, beliefs, expectations and commitment to quality. The values, beliefs, expectations, and commitment to quality that are reflected in a person in carrying out their duties, so that with or without realizing the person concerned has shown job satisfaction, at least in the form of satisfaction if the products or services produced can achieve quality in accordance with established standards. Muya and Wesonga, (2012) suggest that the quality culture in higher education is a complex and sustainable process which implies full involvement and there is no doubt that the culture prevailing in an institution greatly influences its performance. Furthermore, Greenwood and Gaunt $(1994 ; 34)$ suggest that quality culture includes quality-oriented academic standards, the culture that exists within the organization, and the resulting competencies that are quality or quality oriented. (2012) argued that the quality culture in higher education is a complex and sustainable process that implies full involvement and there is no doubt that the culture prevailing in an institution greatly influences its performance. Furthermore, Greenwood and Gaunt $(1994 ; 34)$ suggest that quality culture includes quality-oriented academic standards, the culture that exists within the organization, and the resulting competencies that are quality or quality oriented. (2012) argued that the quality culture in higher education is a complex and sustainable process that implies full involvement and there is no doubt that the culture prevailing in an institution greatly influences its performance. Furthermore, Greenwood and Gaunt $(1994 ; 34)$ suggest that the quality culture includes quality-oriented academic standards, the existing culture within the organization, and the resulting competencies that are quality or quality oriented. Research result Isnanto (2014; 121) found that quality culture has a positive direct effect on customer satisfaction in higher education. The interaction between students, lecturers, and employees during the education process must create a strong quality culture. Therefore, Medan State University should focus on job satisfaction by strengthening lecturers' values, norms, attitudes, beliefs, morals, innovative awareness, competitive awareness, and professional traditions.

The results of the study partially show that participatory leadership has a positive direct effect on the organizational commitment of lecturers by $9.67 \%$. This finding supports the opinion of Gibson, Ivanevich, and Donelly (1997) which states that participation in decisions often has a tendency to experience increased commitment from subordinates. The results of this study also reinforce research by Huang, Shi, Zhang, \& Cheung (2006; 345-367) which 
show that participatory leadership behavior is positively related to organizational commitment for employees. The research results of Atkinson $(2013 ; 38)$ and Wau $(2016 ; 265)$ show that participatory leaders will encourage the contribution and participation of group members and help group members feel relevant and more committed to the decision-making process. Through participatory leadership, it will promote staff commitment and cooperation and strengthen collective identities. The leader's ability to carry out participatory leadership well has an impact on increasing the organizational commitment of lecturers. If the lecturer feels that he has the trust of the leadership and the university, it can make the lecturer have a strong will to do all work and can have an impact on the quality of graduates.

The results of the study partially show that the quality culture has a positive direct effect on the organizational commitment of lecturers by $16.50 \%$. This shows that the commitment of the lecturer organization still needs to be developed so that it reaches a high category. These findings have made clear that the commitment of the lecturer organization is enhanced through the improvement of a quality culture. The quality culture of lecturers at the State University of Medan tends to be "strong" with a strong category of $56.48 \%$. The findings of this study are supportiveresearch conducted by O'Reilly, Chatman, and Caldwell (in Edy Sutrisno, 2010: 280) which concluded that the suitability of organizational members with the prevailing culture can increase productivity, job satisfaction, performance, organizational commitment and the desire to stay in the company. HThe results of research by Situmorang $(2014 ; 215)$, EUA (2006: 10) concluded that quality culture refers to an organizational culture that intends to improve quality permanently which is characterized by two different elements; cultural elements from shared values, beliefs, expectations, and commitment to quality, and from managerial elements through certain processes that can improve quality and aim to coordinate individual activities. Changing organizational culture for the empowerment of quality culture will affect all processes in the system and many influences will be observed in educational activities developed in universities, both formal education, non-formal education and informal education. It can be said that a strong quality culture at the university will be reflected in the commitment of the lecturer organization.

The results of the research partially show that job satisfaction has a positive direct effect on the organizational commitment of lecturers by $17.30 \%$. It should be understood that job satisfaction is a need for every individual at work, especially if job satisfaction reflects pleasant feelings towards various job aspects, which include: supportive working conditions, supportive co-workers, personal fit for work, interpersonal relationships, fair behavior, supervision, and promotion. This pleasant feeling will encourage lecturers to feel happy in working, so that with or without realizing it, the lecturer has shown his organizational commitment to work. To increase job satisfaction, leadership lecturers must respond to the needs of lecturers, by improving the quality of work life or remuneration. If the opportunity to progress and develop and the appreciation for work can be realized, it will be able to increase the commitment of the Medan State University lecturer organization. The findings of this study support researches.Colquit, Lepine, and Wesson (2009: 8) are famous for"Integrative Model of Organizational Behavior", which explains that job satisfaction directly affects organizational commitment, as well as research by Boles et.al (2007; 311-321) and Poerwanti $(2012 ; 111)$ indicates that the job satisfaction facet has a strong relationship with organizational commitment. 


\section{Conclusion}

The model for increasing the commitment of the lecturer organization can be done in two ways, namely: through strengthening participatory leadership, quality culture, and job satisfaction which will directly lead to better organizational commitment. In addition, it can also be done through strengthening participatory leadership, quality culture through which will directly result in an increase in job satisfaction which further increases the commitment of the lecturer organization to be better. Based on the conclusion of this research, it can be done to increase the commitment of the Medan State University lecturer organization through an increase participatory leadership; 2) quality culture; and 4) job satisfaction. Increasing organizational commitment can be done by: 1 ) having trust and accepting the goals and values of the organization; 2) has responsibility for the organization; 3) pride and willingness to work hard to achieve organizational goals; and 4) a strong desire to remain a member of the organization. Improving the quality culture can be done through the empowerment of a quality culture for lecturers through strengthening: 1) values, norms, beliefs and morals; 2) innovative awareness; 3) competitive awareness; and 4) professional tradition. Increasing job satisfaction can be done by: 1) increasing responsibility in carrying out tasks; 2) feeling happy at work; 3) giving awards for achievements and fair promotion opportunities; 4) adjusting people to jobs that are in accordance with the interests and expertise of the brand; and 5) the pleasure of getting feedback from what has been done. 3) pride and willingness to work hard to achieve organizational goals; and 4) a strong desire to remain a member of the organization. Improving the quality culture can be done through the empowerment of a quality culture for lecturers through strengthening: 1) values, norms, beliefs and morals; 2) innovative awareness; 3) competitive awareness; and 4) professional tradition. Increasing job satisfaction can be done by: 1) increasing responsibility in carrying out tasks; 2) feeling happy at work; 3) giving awards for achievements and fair promotion opportunities; 4) adjusting people to jobs that are in accordance with the interests and expertise of the brand; and 5) the pleasure of getting feedback from what has been done. 3) pride and willingness to work hard to achieve organizational goals; and 4) a strong desire to remain a member of the organization.

Improving the quality culture can be done through empowering a quality culture for lecturers through strengthening: 1) values, norms, beliefs and morals; 2) innovative awareness; 3) competitive awareness; and 4) professional tradition. Increasing job satisfaction can be done by: 1) increasing responsibility in carrying out tasks; 2) feeling happy at work; 3) giving awards for achievements and fair promotion opportunities; 4) adjusting people to jobs that are in accordance with the brand's interests and expertise; and 5) the pleasure of getting feedback from what has been done. Improving the quality culture can be done through empowering a quality culture for lecturers through strengthening: 1) values, norms, beliefs and morals; 2) innovative awareness; 3) competitive awareness; and 4) professional tradition. Increasing job satisfaction can be done by: 1) increasing responsibility in carrying out tasks; 2) feeling happy at work; 3) giving awards for achievements and fair promotion opportunities; 4) adjusting people to jobs that are in accordance with the interests and expertise of the brand; and 5) the pleasure of getting feedback from what has been done. Improving the quality culture can be done through the empowerment of a quality culture for lecturers through strengthening: 1) values, norms, beliefs and morals; 2) innovative awareness; 3 ) competitive awareness; and 4) professional tradition. Increasing job satisfaction can be done by: 1) increasing responsibility in carrying out tasks; 2) feeling happy at work; 3) giving awards for achievements and fair promotion opportunities; 4) adjusting people to jobs that are in accordance with the interests and expertise of the brand; and 5) the pleasure of getting feedback from what has been done. 1) increased responsibility in carrying out duties; 2) feeling happy at work; 3) giving awards 
for achievements and fair promotion opportunities; 4) adjusting people to jobs that are in accordance with the interests and expertise of the brand; and 5) the pleasure of getting feedback from what has been done. 1) increased responsibility in carrying out duties; 2) feeling happy at work; 3) giving awards for achievements and fair promotion opportunities; 4) adjusting people to jobs that are in accordance with the interests and expertise of the brand; and 5) the pleasure of getting feedback from what has been done.

\section{References}

Allen, J.N., Meyer, J.P. (1990). The measurement and antecedents of affective, continuance and normative commitment to the organization. Journal of Occupational Psychology, 63, $1-18$.

Arif, Syamsul. (2019). Influence of Leadership, Organizational Culture, Work Motivation and Job Satisfaction of Performance Principles of Senior High School in Medan City. Budapest International Research and Critics Institute (BIRCI-Journal), 239-254.

Benyamin Situmorang, (2012). Pengaruh Budaya Organisasi, Kepemimpinan, Komunikasi Interpersonal, dan Kepuasan Kerja terhadap Komitmen Organisasi Kepala Sekolah. Disertasi. Program Pascasarjana Universitas Negeri Medan.

Benyamin, S. dan Paningkat, S., (2017) Penelitian Pendidikan. Konsep dan Aplikasi. Edisi Revisi. (Medan: PUSSIS Universitas Negeri Medan).p.203

Bogler, R. (2001), "The influence of leadership style on teacher job satisfaction", Educational Administration Quarterly, Vol. 37 No. 5, pp. 662-683.

Dolatabadi, H.R., Safa, M. (2011). The effect of directive and participative leadership style on employee's commitment to service quality. Journal of Business and Management, 4(2)

Egle Katiluite and Bronius Neverauskas, (2009).'Development Quality Culture in the University,"Economic dan Management,Vol.14, hh.1069-1079

Ebru Gunlu, Mehmet Aksarayli,and Niluver sahin Percin, 2010)." Job satisfaction and organizational commitment of hotel maneger in Turkey, International Journal of contemporary Hospitality Mangement, Vol. 22. No. 5, hal 693-717.

Edy Sutrisno (2009). Manajemen Sumber Daya Manusia. Jakarta: Penerbit Kencana.

Effendi, Onong Uchjana (1992). Kepemimpinan dan Komunikasi. Bandung: Mandar Maju.

European University Association. (2006). Quality culture in European universities: A bottom -up approach: Report on the three rounds of the quality culture project 2002-2006. Brussels: European University Association. Retrieved from http: //www. eua.be /eua/jsp/en/upload/Qual ity_Culture 2002_2003. 1150459570109.pdf

EUA. (2011). Examining quality culture part II: processes and tools - participation, ownership and bureaucracy.http://www.eua.be/ Libraries/ Publications _homepage_list/Examinin Quality_Culture_Part_II.sflb.ashx

Fandy Tjiptono dan Anastasia Diana,(2003).Total Quality management .Yogyakarta; Andi, ,h.75.

Fink, S. L. (1992). High commitment workplaces. New York: Quorum Books

Garry Yulk. (2007). Kepemimpinan dalam Organisasi. Edisi Kelima, Alih Bahasa: Budi Supriyanto. Jakarta: Indeks.

Gibson, Ivancevich, Donnely, (1997). Organizations (Terjemahan), Cetakan Keempat. Jakarta: Gelora Aksara Pratama.

Goetsch D.L dan Davis D.L (2002). Introduction to Total Quality: Quality Management for Production, Process, and Service. Edisi Terjemahan. Alih Bahasa oleh Benyamin Molan, Manajemen Mutu Total: Manajemen Mutu untuk Produksi, Pengelolaan, dan Pelayanan. Jilid I. Jakarta: PT Prenhalindo. 
Harun Al-Rasjid (1994). Analisis Jalur (Path Analysis). Bandung: FMIPA Universitas Padjadjaran.

Huang, X., Shi, K., Zhang, Z., \& Cheung, Y.L. (2006).The impact of participative leadership behavior on psychological empowerment and organizational commitment in Chinese state-owned enterprises: The moderating role of organizational tenure. Asia Pacific Journal Management. 23, ,345-367

Isnanto (2014). Pengaruh Budaya Mutu, Iklim Akademik, dan Kinerja Dosen terhadap Kepuasan Pelanggan di Fakultas Ilmu Pendidikan Universitas Gorontalo. Disertasi. Program Pascasarjana Universitas Negeri Jakarta. P.121

James Boles, Ramana Manupalli, Brian Ruterford, and John Andy Wood,( 2007). "The relationship of facets of salesperson job satisfaction with affective organizational commitment", Journal of Business \& Idustrial Marketing, Vol. 22, No. 5, hal.311-321.

Jason A. Colquitt, Jeffery A. Lepine, dan Michael J. Wesson (2009). Organization Behavior: Improving Performance and Commitment in the Workplace. New York: The McGrawHill Com., Inc.

John W. Newstrom. (2007). Organizational Behavior, Twelfth Edition. Boston: McGraw Hill.

Lambert, E.G., Hogan, N.L., Jiang, S. (2008). Exploring antecedents of five types of organizational commitment among correctional staff: It matters what you measure. Criminal Justice Policy Review.

Luthans, Fred, (2006), Organizational Behavior. New York: McGraw Hill.

Magdalena Iodarche and Eleonara Gabriela, (2011).Leadership Importance and role in the public sector-features in the contemporary context, Journal of challangers of the knowledge sosiety economy, pp 1361-1369.

Malcom S. Greenwood dan Helen J. Gaunt, (1994). Total Quality Management for School. New York: Cassell, h.34.

Mangkunegara Anwar Prabu. 2005. Manajemen Sumber Daya Manusia Perusahaan, Cetakan Keenam. Bandung: Remaja Rosdakarya.

Mullins, Lauriel J. (2005). Management and Organizational Behavior. Edinburg Gate Harlow: Prentice Hall, Inc.

Muya, J. N., \& Wesonga, J. N. (2012). The impact of Organisational Culture on Performance of Educational Institutions. International Journal of Business and Social Science, 3(8) Retrieved from http://search.proquest.com/docview/1010404274? accountid=15533 Omerzel, D. G.,

Ning Hong. (2008).'Discussion on Enterrise Quality Culture Significance”, Journal of Science and Technology Information, Vol.5,No.18,hh.71-76.

Northouse,P. G. (2013). Leadership theory and practice 6th edition. Sage Publication, Inc. Retrieved November 26, 2013 available at http://books.google.co.id/books? id=MIKDJx2YHSIC\&printsec $=$ frontcover\#v $=$ onepage $\& q \& \mathrm{f}=$ fals $\mathrm{e}$

Richard L. D., (2005). The Leadership Experience, 3rd edition.

Sihombing, T. et al. (2020). The Effect of Accounting Information and OrganizationalCulture on Decision Making. Budapest International Research and Critics Institute-Journal (BIRCI-Journal). P. 522-530

Syardiansah, et al. (2020). The Effect of Job Satisfaction and Organizational Culture on Employee Performance of the Royal Hotel in East Aceh District. Budapest International Research and Critics Institute-Journal (BIRCI-Journal). P. 849-857

Stephen P. Robbins dan Timothy A. Judge (2009). Organizational Behavior. New Jersey: Pearson Prentice Hall.

Stevens, C. D., and Ash, R. A. (2001), "Selecting employees for fit: Personality and preferred managerial style", Journal of Managerial Issues, Vol. 13, pp. 500-517 
Taras, V., Steel, P., and Kirkman, B. L. (2011), "Three decades of research on national culture in the workplace: Do the differences still make a difference?." Organizational Dynamics, Vol. 40 No. 3, pp. 189-198.

Tsui, K. T., \& Cheng Y. C. (1999). School organizational health and teacher commitment: A contingency study with multi-level analysis. Educational Research and Evaluation, 5, 249-26

Wagner, S. E. (2006), "Staff retention from 'satisfied' to 'engaged', Nursing Management, Vol. 37, pp. 25-29.

Yasarotodo Wau, (2012) "Pengaruh kepemimpinan partisipatif, kemampuan pribadi, iklim kerja, dan motivasi berprestasi terhadap komitmen afektif', Disertasi, Program Pascasarjana Universitas Negeri Medan, hal.265.

Yuni Poerwanti,( 2012) "Pengaruh Karakteristik Pekerjaan, Kebijakan Organisasi, dan Kepuasan Kerja terhadap Komitmen Organisasional Pegawai Kementrian Pemuda dan Olahraga Republik Indonesia", Disertasi , Program Pascasarjana Universitas Negeri Jakarta, hal.111. 